\title{
Interactions of Organic Acids with Salmonella Strains from Feedlot Water-Sprinkled Cattle
}

Ross C. Beier, Todd R. Callaway, Kathleen Andrews, Toni L. Poole, Tawni L. Crippen, Robin C. Anderson and David J. Nisbet Southern Plains Agricultural Research Center, Agricultural Research Service, U.S. Department of Agriculture, College Station, TX 77845, USA

Correspondence to:

Ross C. Beier

Food and Feed Safety Research Unit

Southern Plains Agricultural Research Center

United States Department of Agriculture

2881 F\&B Road,College Station, TX, USA

Tel: (979) 260-9411

Fax: (979) 260-9332

E-mail: ross.beier@ars.usda.gov

Received: March 06, 2017

Accepted: May 04, 2017

Published: May 08, 2017

Citation: Beier RC, Callaway TR, Andrews K, Poole TL, Crippen TL, et al. 2017. Interactions of Organic Acids with Salmonella Strains from Feedlot Water-Sprinkled Cattle. J Food Chem Nanotechnol 3(2): 60-66.

Copyright: (C) 2017 Beier et al. This is an Open Access article distributed under the terms of the Creative Commons Attribution 4.0 International License (CC-BY) (http://creativecommons. org/licenses/by/4.0/) which permits commercial use, including reproduction, adaptation, and distribution of the article provided the original author and source are credited.

Published by United Scientific Group

\begin{abstract}
Organic acids are commonly used as a carcass wash to remove bacterial loads during food production. In this study the interactions of four organic acids with 145 Salmonella strains comprised of six different serovars from feedlot watersprinkled cattle were studied. The $\mathrm{pH}$ was determined at the molar MICs $\left(\mathrm{MIC}_{\mathrm{M}} \mathrm{s}\right)$ of the Salmonella strains. The concentrations of the undissociated and dissociated organic acids were calculated at the $\mathrm{MIC}_{\mathrm{M}} \mathrm{s}$ of the Salmonella strains using the Henderson-Hasselbalch equation. Since all Salmonella strains behaved similarly to the different organic acids, the results of the six different Salmonella serovars Anatum, Cerro, Gaminara, Kentucky, Meleagridis and Muenster hide and feces strains were treated as a single group for each organic acid, acetic, citric, lactic and propionic acid. Bacterial inhibition was not solely dependent on $\mathrm{pH}$ or on the undissociated organic acid species, but was correlated with the dissociated organic acid species. A small drop in the concentration of the dissociated organic acids may result in a large number of bacteria escaping disinfection. Therefore, an organic acid carcass wash may not provide the expected elimination of surface bacteria if the concentration of dissociated organic acid is not carefully controlled. We suggest to maintain a concentration of dissociated propionic, acetic, lactic and citric acids of 15, 16, 17 and $20 \mathrm{mM}$, respectively, when carrying out a carcass wash with these organic acids to remove Salmonella enterica strains.
\end{abstract}

\section{Keywords}

Acetic acid, Citric acid, Feedlot cattle, Lactic acid, Organic acids, Propionic acid, Salmonella, Susceptibility, Water-sprinkled cattle

\section{Introduction}

Salmonella enterica is a major pathogen causing infections from foodborne sources and is a threat to human health in the United States [1] as well as throughout the world [2]. The Centers for Disease Control and Prevention (CDC) has estimated that each year Salmonella causes one million foodborne illnesses in the United States alone, with 19,000 hospitalizations and 380 deaths [3]. Salmonella ranks only $2 \mathrm{nd}$ in the list of the top five bacterial pathogens contributing to domestically acquired foodborne illnesses in the United States [4]. However, the CDC has linked over 9 million cases of foodborne illness to 31 major pathogens [5]. Of these 31 pathogens, 15 pathogens are primarily associated with $95 \%$ or more of the total economic burden of foodborne illnesses, hospitalizations and deaths, and Salmonella ranks number one in this list of these 15 pathogens [4]. An analysis of the risk of Salmonella illness per serving of beef, lamb, pork, and poultry suggests there is a similar risk of illness from the four different meats [6]. The top ten Salmonella serovars isolated from commercial ground beef over a period from July 2005 to June 2007 were Montevideo, Anatum, Muenster, Mbandaka, Agona, 
Cerro, Meleagridis, Typhimurium, Dublin and Kentucky [7]. These ten Salmonella serovars also have been associated with outbreaks of foodborne illness: Montevideo [8, 9], Anatum [10], Muenster [11], Mbandaka [8], Agona [12], Cerro [13, 14], Meleagridis [15], Typhimurium [16-18], Dublin [19, 20] and Kentucky [21, 22], to list a few instances.

Strategies used to control bacteria in the food chain continuum include the use of biocides as antiseptics and disinfectants [23]. The strategies to control pathogens must be comprehensive, following food products from the farm to the table [24]. An important step in processing beef is to acid wash the carcasses. Organic acids are used to perform the acid wash. The organic acids generally used are acetic $[25,26]$, citric [27], lactic [25-28] and propionic acids [26]. The acid wash step is very important to remove the bacteria carried along on the carcasses. Bacteria not removed from the carcass may turn up in sliced or ground meat. Therefore, the acid wash step should be studied. Recently, the Salmonella serovars Anatum, Montevideo and Kentucky were identified in cattle feces during a study to determine the prevalence of Salmonella enterica in South Texas beef cattle feedlots [29]. These Salmonella serovars are among the top 10 Salmonella serovars isolated from commercial ground meat [7], and can be important players in outbreaks of foodborne illness [8-10, 21, 22].

Researchers have often thought that bacterial inhibition by organic acids was dependent solely on $\mathrm{pH}$ or the undissociated acid species [30-32]. But the specific mechanisms by which $\mathrm{pH}$ and organic acids inhibit bacteria are not completely understood [33]. We have previously evaluated Escherichia coli O157:H7 strains from cattle carcasses, feces and hides and ground beef [34], Pseudomonas aeruginosa veterinary isolates [35], and the organic acid inhibition was clearly associated with the dissociated acid species. The disintegration of the LPS layer can be caused by a fully dissociable acid [36]. In a recent study of the big six non-O157 Shiga toxin-producing E. coli (non-O157 STEC) [37], overall, the dissociated acid concentrations were more closely correlated with the molar minimum inhibitory concentrations $\left(\mathrm{MIC}_{\mathrm{M}} \mathrm{s}\right)$. However, both the dissociated acid form and the undissociated acid form may play a part in bacterial inhibition [36].

In this present study, we describe the interactions of organic acids with six Salmonella serovars obtained in an earlier study of water-sprinkling on the incidence of zoonotic pathogens in feedlot cattle [38]. The susceptibility of Salmonella serovars Anatum, Cerro, Gaminara, Kentucky, Meleagridis and Muenster to the organic acids acetic, citric, lactic and propionic acids were conducted here. Comparisons are shown of the $\mathrm{MIC}_{\mathrm{M}} \mathrm{s}$ vs. the $\mathrm{pH}$, undissociated acid species and dissociated acid species.

\section{Materials and Methods}

\section{Salmonella enterica serovars}

Salmonella enterica serovars Kentucky (20), Meleagridis (7) and Muenster (19) were isolated from the feces and the $S$. enterica serovars Anatum (1), Cerro (9), Gaminara (1),
Kentucky (45), Meleagridis (13) and Muenster (30) were isolated from the hides of Charolais-crossbred heifers at a commercial feedlot in Lockney, TX, USA [38]. Salmonella strains were stored in glycerol and TSB at $-80^{\circ} \mathrm{C}$ until used. All cultures were then grown for $24 \mathrm{~h}$ at $37^{\circ} \mathrm{C}$ on trypticase soy agar w/5\% sheep blood BBL Stacker Plates (Becton, Dickinson and Company, Sparks, MD, USA).

\section{Organic acid susceptibility testing}

MICs for the organic acids were determined by broth microdilution according to the Clinical and Laboratory Standards Institute (CLSI) [39]. MICs were determined as the lowest concentration of a compound that showed no visible growth of the organism [40]. The organic acid susceptibility studies were carried out similarly to earlier studies with other pathogens $[34,35,37]$. Briefly, $50 \mu \mathrm{L}$ of each organic acid solution was diluted 1:2 across a 96-well U-bottom Greiner bio-one microplate ((\#82050-626, VWR, Houston, TX, USA) through column 11, and column 12 was the positive control. Several well-isolated colonies were selected from a sheep blood agar plate culture. The growth was transferred to a $5 \mathrm{~mL}$ Sensititre ${ }^{\circledR}$ demineralized water tube and adjusted to a $0.5 \mathrm{McF}$ arland Standard using a Sensititre ${ }^{\circledR}$ Nephelometer ${ }^{\circledR}$ (Remel, Lenexa, KS, USA). Then $50 \mu \mathrm{L}$ of the bacterial solution was transferred into $11 \mathrm{~mL}$ Sensititre ${ }^{\circledR}$ Mueller-Hinton broth with TES buffer to give an inoculum of approximately $9 \times 10^{5} \mathrm{CFU} / \mathrm{mL}$. Then, $50 \mu \mathrm{L}$ of inoculum was added to each well of the $96-$-well plate. The plates were covered with a plastic adhesive sealing film, SealPlate ${ }^{\circledR}$ (EXCEL Scientific, Inc., Victorville, CA, USA) and incubated for $20 \mathrm{~h}$ at $37^{\circ} \mathrm{C}$. Growth in the wells was visually observed using a Sensititre ${ }^{\circledR}$ SensiTouch ${ }^{\circledR}$ (Remel, Lenexa, KS, USA). Escherichia coli ATCC 25922 was used as a control organism for the organic acid susceptibility testing.

Acetic acid was obtained from EM Science (Gibbstown, NY, USA). Citric acid and propionic acid were obtained from Sigma-Aldrich (Milwaukee, WI, USA). Lactic acid was obtained from Alfa Aesar (Ward Hill, MA, USA). The organic acids were diluted with reverse osmosis water to make working solutions and then filter-sterilized using $0.2 \mu \mathrm{m} \times 25$ mm syringe filters (No. 431224, Corning Inc., Corning, NY, USA). The following concentrations of organic acids were tested: Two-fold dilutions of acetic acid, 32-32,768 $\mu \mathrm{g} / \mathrm{mL}$; citric acid, 16-16,384 $\mu \mathrm{g} / \mathrm{mL}$; lactic acid, 8-8,192 $\mu \mathrm{g} / \mathrm{mL}$; and propionic acid, $32-32,768 \mu \mathrm{g} / \mathrm{mL}$ were used. The $\mathrm{pH}$ of the solutions was not adjusted.

\section{$\mathrm{pH}$ determination of solutions in the wells at the MICs}

The $\mathrm{pH}$ was determined by combining the solutions in 16 wells $(1,600 \mu \mathrm{L})$ at the same MIC value for each organic acid and for all MICs. The $\mathrm{pH}$ was measured using an Orion 3 STAR benchtop $\mathrm{pH}$ meter with a ROSS Ultra, glass combination $\mathrm{pH}$ electrode (\#8102BNOWP, Thermo Fisher Scientific, Chelmsford, MA, USA). Each $\mathrm{pH}$ determination at an MIC was conducted in triplicate.

\section{Calculation of the ratio of undissociated to dissociated acids}

The ratio of the dissociated acid to the undissociated 
acid can be calculated when the $\mathrm{pH}$ is known by using the Henderson-Hasselbalch equation [41]:

$$
\mathrm{pH}=\mathrm{pK}_{\mathrm{a}}+\log \left(\left[\mathrm{A}^{-}\right] /[\mathrm{HA}]\right)
$$

Where the $\mathrm{pK}_{\mathrm{a}}$ is $-\log _{10}$ of the acid dissociation constant $\left(\mathrm{K}_{\mathrm{a}}\right),\left[\mathrm{A}^{-}\right]$is the molar concentration of the conjugate base (or dissociated weak acid), and [HA] is the molar concentration of the undissociated weak acid. The Henderson-Hasselbalch equation can be rearranged to give the ratio of undissociated acid to the dissociated acid [31]:

$$
\text { ratio }=[\mathrm{HA}] /\left[\mathrm{A}^{-}\right]=1 / 10^{\mathrm{pH}-\mathrm{pKa}}
$$

Therefore, when the $\mathrm{pK}_{\mathrm{a}}$ of the acid in question and the $\mathrm{pH}$ of the solution are known, then the ratio of the undissociated acid to the dissociated acid can be calculated. The $\mathrm{pK}_{\mathrm{a}}$ for acetic, citric, lactic and propionic acid is $4.75,3.14,3.86$ and 4.87 , respectively. If the molar concentration of the acid is known, then the concentrations of the undissociated acid and dissociated acid species can be calculated from the ratio.

\section{Results}

$\mathrm{pH}$ associated with Salmonella MICs against the organic acids

The Salmonella MICs and $\mathrm{MIC}_{\mathrm{M}} \mathrm{s}$ against the organic acids are shown in Table 1 . The MICs for acetic, citric, lactic and propionic acids are quite similar between the different Salmonella serovars, Anatum, Cerro, Gaminara, Kentucky, Melagridis and Muenster, and the MICs are nearly identical for the same serovars obtained from either cattle hides or feces. Since all Salmonella serovars behaved similarly for each organic acid tested, the recorded $\mathrm{pH}$ at the $\mathrm{MIC}_{\mathrm{M}} \mathrm{s}$ for all strains ( $\mathrm{n}=$ 145) were combined into a single group at each MIC for each organic acid. Figure 1 shows a graphical representation of the $\mathrm{pH}$ obtained at the $\mathrm{MIC}_{\mathrm{M}} \mathrm{s}$ of the four organic acids with the 145 Salmonella strains. The number of strains at each $\mathrm{MIC}_{\mathrm{M}}$ is shown next to each data point. The $\mathrm{MIC}_{\mathrm{M}}$ for $97.2 \%$ of the strains against acetic acid occurred at $\mathrm{pH}$ 5.15. The $\mathrm{MIC}_{\mathrm{M}}$ for $100 \%$ of the strains against propionic acid occurred at $\mathrm{pH}$

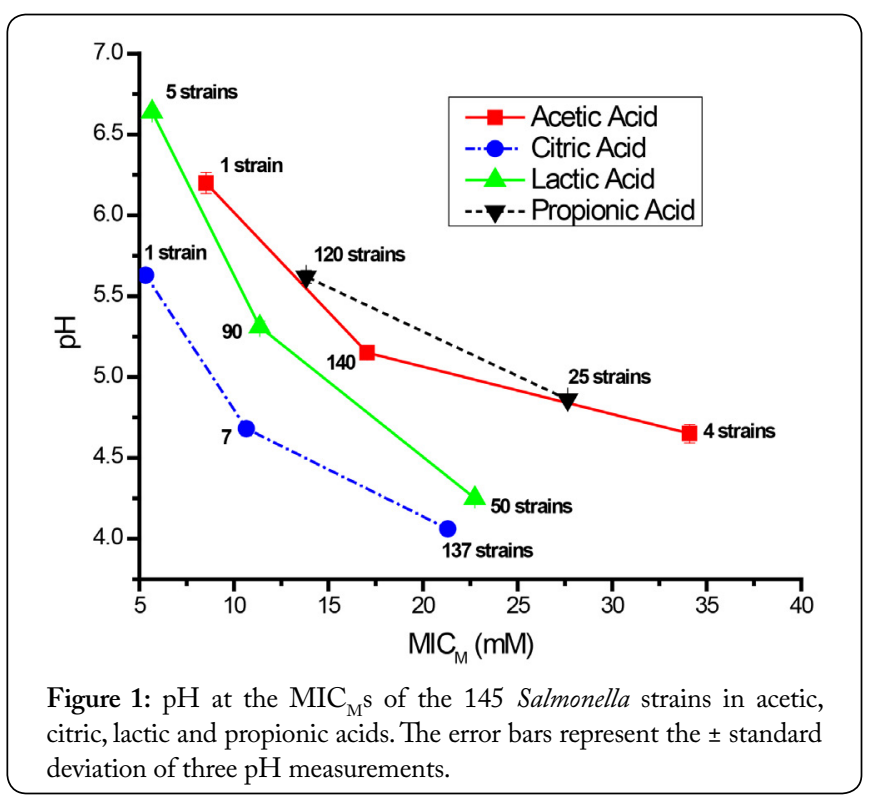

4.86. But the $\mathrm{MIC}_{\mathrm{M}}$ for $100 \%$ of the strains against citric and lactic acids occurred at $\mathrm{pH} 4.06$ and $\mathrm{pH} 4.25$, respectively. This is almost a $\mathrm{pH}$ unit difference between the inhibition of $100 \%$ of the bacteria by acetic and propionic acid and the inhibition by citric and lactic acids.

The organic acids characteristic profiles of their interactions with the individual Salmonella serovars from hides and feces are shown in detail in the Supplemental Material (SM). The following $\mathrm{SM}$ figures show the $\mathrm{pH}$ vs. $\mathrm{MIC}_{\mathrm{M}} \mathrm{s}$ in respect to acetic, citric, lactic and propionic acids against the animal hide strains from serovars Anatum (Figure S1), Cerro (Figure S2), Gaminara (Figure S3), Kentucky (Figure S4), Meleagridis (Figure S5) and Muenster (Figure S6), and against the animal feces strains from serovars Kentucky (Figure S7), Meleagridis (Figure S8) and Muenster (Figure S9).

Calculated concentrations of the undissociated organic acids at the Salmonella $\mathrm{MIC}_{\mathrm{M}} \mathrm{s}$

Figure 2 shows the distribution of Henderson-Hasselbalch calculated undissociated acid concentrations for acetic, citric, lactic, and propionic acids at the $\mathrm{MIC}_{\mathrm{M}}$ of the 145 Salmonella strains. The undissociated acetic acid concentration at the $\mathrm{MIC}_{\mathrm{M}}$ of $100 \%$ of the Salmonella strains tested was $19.0 \mathrm{mM}$. The undissociated citric acid concentration at the $\mathrm{MIC}_{\mathrm{M}}$ of $100 \%$ of the Salmonella strains tested was $2.29 \mathrm{mM}$. The shaded band in Figure 2 shows the difference of $16.71 \mathrm{mM}$ concentration whereby $100 \%$ of the strains would be inhibited by either the undissociated acetic acid or undissociated citric acid.

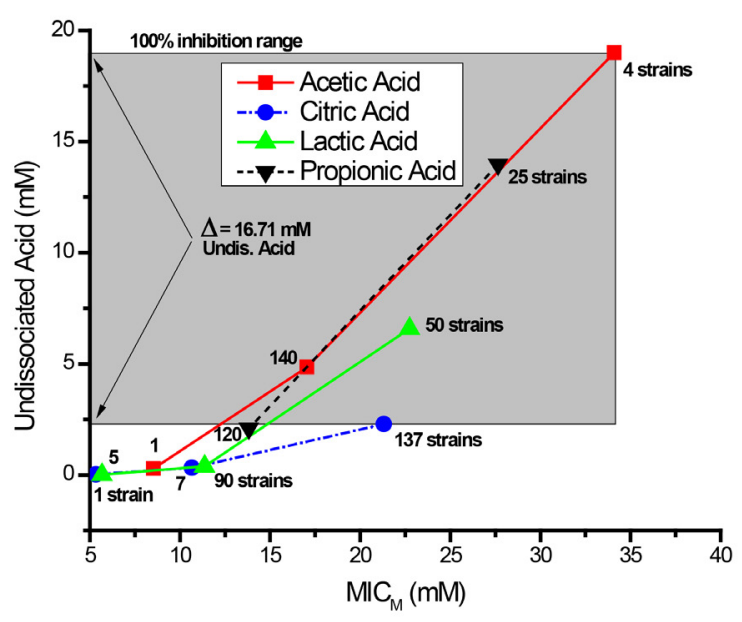

Figure 2: Concentrations of the undissociated acetic, citric, lactic and propionic acids at the $\mathrm{MIC}_{\mathrm{M}}$ s of the 145 Salmonella strains. The grey band shows a difference of $16.71 \mathrm{mM}$ between the undissociated organic acids, acetic, citric, lactic and propionic acids required for disinfection of $100 \%$ of the Salmonella strains.

The following SM figures show the undissociated acid species vs. $\mathrm{MIC}_{\mathrm{M}} \mathrm{s}$ in respect to acetic, citric, lactic and propionic acids against the animal hide strains from the individual serovars Anatum (Figure S10), Cerro (Figure S11), Gaminara (Figure S12), Kentucky (Figure S13), Meleagridis (Figure S14) and Muenster (Figure S15), and against the animal feces strains from serovars Kentucky (Figure S16), Meleagridis (Figure S17) and Muenster (Figure S18). 


\begin{tabular}{|c|c|c|c|c|c|c|c|c|c|c|}
\hline & & \multicolumn{9}{|c|}{ Serovars } \\
\hline \multirow{2}{*}{\multicolumn{2}{|c|}{ No. total Bacteria }} & Anatum & Cerro & Gaminara & \multicolumn{2}{|c|}{ Kentucky } & \multicolumn{2}{|c|}{ Meleagridis } & \multicolumn{2}{|c|}{ Muenster } \\
\hline & & 1 & 9 & 1 & 45 & 20 & 13 & 7 & 30 & 19 \\
\hline \multicolumn{2}{|r|}{ Source } & Hide & Hides & Hide & Hides & Feces & Hides & Feces & Hides & Feces \\
\hline $\begin{array}{c}\text { MICc }^{c} \\
(\mu \mathrm{g} / \mathrm{mL})\end{array}$ & $\begin{array}{l}\mathrm{MIC}_{M} \\
(\mathrm{mM})\end{array}$ & \multicolumn{9}{|c|}{ No. of Bacteria at an Acid MIC } \\
\hline \multicolumn{11}{|l|}{ Acetic Acid } \\
\hline 2048 & 34.1 & & & & 1 & 1 & 1 & 1 & & \\
\hline 1024 & 17.05 & 1 & 9 & 1 & 44 & 19 & 12 & 6 & 30 & 18 \\
\hline 512 & 8.53 & & & & & & & & & 1 \\
\hline \multicolumn{11}{|l|}{ Citric Acid } \\
\hline 4096 & 21.32 & 1 & 8 & 1 & 45 & 20 & 11 & 6 & 27 & 18 \\
\hline 2048 & 10.66 & & 1 & & & & 2 & 1 & 2 & 1 \\
\hline 1024 & 5.33 & & & & & & & & 1 & \\
\hline \multicolumn{11}{|l|}{ Lactic Acid } \\
\hline 2048 & 22.74 & & 7 & & 18 & 4 & 6 & 3 & 3 & \\
\hline 1024 & 11.37 & 1 & 2 & 1 & 27 & 14 & 7 & 4 & 26 & 17 \\
\hline 512 & 5.68 & & & & & 2 & & & 1 & 2 \\
\hline \multicolumn{11}{|c|}{ Propionic Acid } \\
\hline 2048 & 27.65 & 1 & & & 8 & 3 & 4 & 3 & 4 & 2 \\
\hline 1024 & 13.82 & & 9 & 1 & 37 & 17 & 9 & 4 & 26 & 17 \\
\hline \multicolumn{11}{|c|}{$\begin{array}{l}{ }^{a} \mathrm{MIC}_{\mathrm{M}} \mathrm{s}=\text { Molar MICs } \\
\text { b Strains were grown for } 24 \mathrm{~h} \text { at } 37^{\circ} \mathrm{C} \text { on trypticase soy agar w/5\% sheep blood, and the growth was transferred into Mueller-Hinton broth with TES } \\
\text { buffer to give an inoculum of approximately } 9 \times 10^{5} \mathrm{CFU} / \mathrm{mL} \text {. The inoculum }(50 \mu \mathrm{L}) \text { was layered on top of } 50 \mu \mathrm{L} \text {-acid solutions in each well of a } 96 \text {-wel } \\
\text { U-bottom plate. The plates were covered with adhesive sealing film and incubated for } 20 \mathrm{~h} \text { at } 37^{\circ} \mathrm{C} \text {. } \\
{ }^{\mathrm{c}} \mathrm{MICs} \text { were visually determined using a Sensititre }{ }^{\circledR} \text { SensiTouch } \circledast \text {. }\end{array}$} \\
\hline
\end{tabular}

Calculated concentrations of the dissociated organic acids at the Salmonella $\mathrm{MIC}_{\mathrm{M}} \mathrm{s}$

Concentrations of the calculated dissociated organic acids, acetic, citric, lactic and propionic acids at the $\mathrm{MIC}_{\mathrm{M}}$ of the 145 Salmonella strains are shown in Figure 3. The shaded band in Figure 3 indicates the molar dissociated organic acid concentrations required to produce the $\mathrm{MIC}_{\mathrm{M}} \mathrm{S}$ for $100 \%$ of the 145 Salmonella strains by all four acids. There is a difference in $5.36 \mathrm{mM}$ concentration between the four dissociated organic acids that produce the $\mathrm{MIC}_{\mathrm{M}} \mathrm{s}$ for $100 \%$ of the 145 Salmonella strains. This difference results from a dissociated acid concentration of $19.03 \mathrm{mM}$ for citric acid and a dissociated acid concentration of $13.67 \mathrm{mM}$ for propionic acid. But there is only a concentration difference of $1.43 \mathrm{mM}$ between the dissociated acetic acid and dissociated propionic acid concentrations that produced the $\mathrm{MIC}_{\mathrm{M}^{\mathrm{S}}}$ for $100 \%$ of the 145 Salmonella strains.

The following SM figures show the dissociated acid species vs. $\mathrm{MIC}_{\mathrm{M}} \mathrm{s}$ in respect to acetic, citric, lactic and propionic acids against the animal hide strains from serovars Anatum (Figure S19), Cerro (Figure S20), Gaminara (Figure S21), Kentucky (Figure S22), Meleagridis (Figure S23) and Muenster (Figure S24), and against the animal feces strains from serovars Kentucky (Figure S25), Meleagridis (Figure S26) and Muenster (Figure S27).

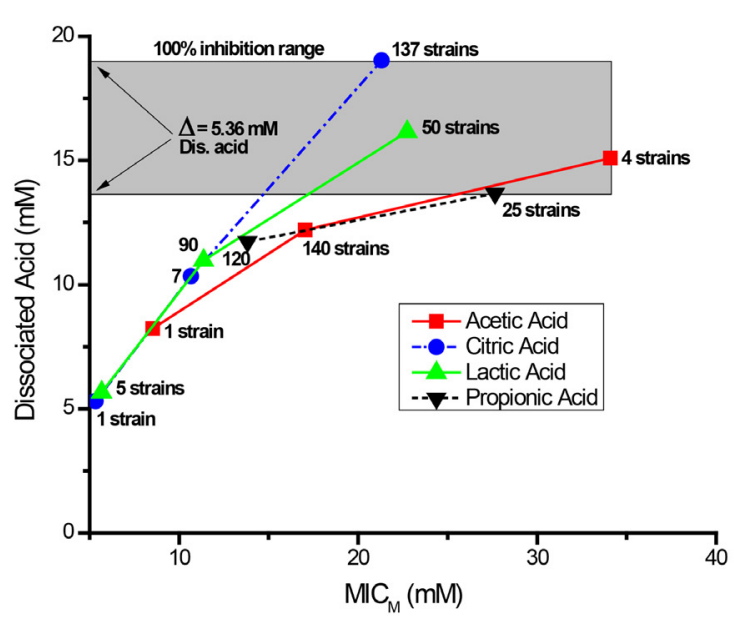

Figure 3: Concentrations of the dissociated acetic, citric, lactic and propionic acids at the $\mathrm{MIC}_{\mathrm{M}} \mathrm{s}$ of the 145 Salmonella strains. The grey band shows a difference of $5.36 \mathrm{mM}$ between the levels of all dissociated organic acids, acetic, citric, lactic and propionic acids required for disinfection of $100 \%$ of the Salmonella strains.

\section{Discussion}

When Salmonella strains were subjected to acetic and propionic acids, the MICs for $99.3 \%$ and $100 \%$ of the strains occurred at a $\mathrm{pH}$ of approximately 5.2 and 4.9, respectively. 
A $\mathrm{pH}$ of approximately 4.1 and 4.2 was measured at the MICs of $94.5 \%$ and $96.6 \%$ of the strains when they were subjected to citric and lactic acids, respectively. This nearly 1 $\mathrm{pH}$ unit difference in $\mathrm{pH}$ at the MICs of the two acid groups indicate that the MICs of these organic acids were not solely dependent on the $\mathrm{pH}$ of the acids, as has been suggested by others [31], but rather some other aspect of these acids. If $\mathrm{pH}$ were the primary factor in inhibition of the bacteria, then one would expect the MICs for these same bacteria for all the different acids would be at the same $\mathrm{pH}$ value, but that is not the case. The Salmonella strains demonstrated similar behavior against the organic acids as did E. coli O157:H7 [34], non-O157 STECs [37] and P. aeruginosa [35], except the $\mathrm{pH}$ values for the $E$. coli $\mathrm{O} 157: \mathrm{H} 7$ strains were somewhat lower, possibly because O157:H7 strains are known to have multiple acid-resistance systems to protect them from extreme acid stress [42]. After comparing the study here of Salmonella strains to the previous three studies, E. coli O157:H7 [34], the non-O157 STECs [37] and P. aeruginosa [35], we observed a trend beginning to develop. The $\mathrm{MIC}_{\mathrm{M}} \mathrm{s}$ of $100 \%$ of the Salmonella strains with acetic acid was at $\mathrm{pH} 4.9,98.6 \%$ of non-O157 STECs with acetic acid was at $\mathrm{pH} 4.79$ [37] and the $\mathrm{MIC}_{\mathrm{M}}$ s of $99 \%$ of the $P$. aeruginosa strains with acetic acid was at $\mathrm{pH} 4.9$ [35]. Since E. coli O157:H7 has glutamateand arginine-dependent acid-resistance systems to protect it from extreme acid stress [42], we see more acid-tolerance in E. coli $\mathrm{O} 157: \mathrm{H} 7$. The $\mathrm{MIC}_{\mathrm{M}} \mathrm{s}$ of $99.3 \%$ of the E. coli $\mathrm{O} 157: \mathrm{H} 7$ with acetic acid were somewhat lower at $\mathrm{pH} 4.29$, but citric and lactic acids had a profound effect resulting in the $\mathrm{MIC}_{\mathrm{M}} \mathrm{s}$ of $98.2 \%$ of the E. coli $\mathrm{O} 157: \mathrm{H} 7$ strains at $\mathrm{pH} 3.95$ and $\mathrm{pH}$ 3.73, respectively [34]. The $\mathrm{MIC}_{\mathrm{M}}$ s for the major portion of the Salmonella strains here with citric and lactic acids were also observed about $1 \mathrm{pH}$ unit lower at $\mathrm{pH} 4.1$ and $\mathrm{pH}$ 4.2. Salmonella enterica also has efflux systems, and efflux pumps or overexpressed efflux pumps can contribute too many classes of chemical resistance [43]. Also, S. enterica has been shown to display arginine-dependent acid-resistance [44]. The $\mathrm{MIC}_{\mathrm{M}} \mathrm{s}$ for $100 \%$ of the non-O157 STECs with citric and lactic acids were at $\mathrm{pH} 4.08$ and $\mathrm{pH} 3.98$, respectively [37]. However, the $\mathrm{MIC}_{\mathrm{M}} \mathrm{s}$ for $98 \%$ of the $P$. aeruginosa strains with citric and lactic acids were at $\mathrm{pH} 4.53$ and $\mathrm{pH}$ 5.28, respectively [35]. The result obtained for $P$. aeruginosa [35] may well be different since $P$. aeruginosa is known to utilize lactate $[45,46]$.

The 100\% inhibition range for all four undissociated organic acids, acetic, citric, lactic and propionic for the 145 Salmonella strains extends from $2.29 \mathrm{mM}$ undissociated citric acid to $19.0 \mathrm{mM}$ undissociated acetic acid. This is a difference of $16.71 \mathrm{mM}$ across the four acid species. There appears to be no correlation as to the concentration of undissociated acids with the $\mathrm{MIC}_{\mathrm{M}} \mathrm{s}$ for the 145 strains. These results are consistent with results obtained with E. coli O157:H7 [34] and with the non-O157 STECs [37]. The undissociated acetic, lactic and citric acids had a difference in concentration of $47.77 \mathrm{mM}$ for 98.3\% of the 344 E. coli O157:H7 strains at their $\mathrm{MIC}_{\mathrm{M}^{\mathrm{s}}}$ [34]. The undissociated acetic, citric, lactic and propionic acids had a difference in concentration of $14.07 \mathrm{mM}$ for $98.6 \%$ of the 138 non-O157 STEC strains at their $\mathrm{MIC}_{\mathrm{M}} \mathrm{s}$ [37]. In both of these previous studies, as in this study with Salmonella, there was no indication of a correlation between the concentrations of undissociated acid with the $\mathrm{MIC}_{\mathrm{M}} \mathrm{s}$.

There was a relatively small dissociated acid concentration window for the $\mathrm{MIC}_{\mathrm{M}} \mathrm{s}$ of the 145 strains of Salmonella for all four organic acids tested. This window had a difference in concentration of $5.36 \mathrm{mM}$ and ranged between $13.67 \mathrm{mM}$ dissociated propionic acid to $19.03 \mathrm{mM}$ dissociated citric acid. This result was very similar to that observed for E. coli O157:H7 [34]. The dissociated acetic, citric, lactic and propionic acids had a difference in concentration of $5.44 \mathrm{mM}$ at the $\mathrm{MIC}_{\mathrm{M}} \mathrm{s}$ of $98.3 \%$ of the $344 \mathrm{E}$. coli $\mathrm{O} 157: \mathrm{H} 7$ strains tested [34]. The concentration window ranged between $13.8 \mathrm{mM}$ dissociated propionic acid to $19.36 \mathrm{mM}$ dissociated lactic acid. The results observed here with Salmonella enterica are also very similar to that observed for the non-O157 STECs [37]. The dissociated acetic, citric, lactic and propionic acids had a difference in concentration of $6.19 \mathrm{mM}$ at the $\mathrm{MIC}_{\mathrm{M}} \mathrm{s}$ of $100 \%$ of the 138 non-O157 STEC strains tested [37]. The concentration window ranged between $12.93 \mathrm{mM}$ dissociated lactic acid to $19.12 \mathrm{mM}$ dissociated citric acid. Also, the dissociated acetic and citric acids had a very small difference in concentration at the $\mathrm{MIC}_{\mathrm{M}}$ s of $98 \%$ of the 175 P. aeruginosa strains tested [35]. Only a difference in concentration of $0.26 \mathrm{mM}$ was observed for the dissociated acetic and citric acids at the $P$. aeruginosa $\mathrm{MIC}_{\mathrm{M}} \mathrm{s}$, which ranged between $9.98 \mathrm{mM}$ dissociated acetic acid to $10.24 \mathrm{mM}$ dissociated citric acid [35].

It is abundantly clear that the dissociated organic acids have a good correlation with the $\mathrm{MIC}_{\mathrm{M}}$ for $E$. coli O157:H7 [34], P. aeruginosa [35], non-O157 STECs [37], and for the 145 Salmonella strains in this study isolated from feedlot water-sprinkled cattle. However, it has been thought that both the dissociated acid form as well as the undissociated acid form may play a role in inhibiting bacteria [36]. We suggest that during the use of the organic acids tested here to control Salmonella enterica strains, a dissociated acid content of about 15, 16, 17 and $20 \mathrm{mM}$ propionic, acetic, lactic and citric acids, respectively, be maintained during use of organic acid carcass wash procedures, except for the use of lactic acid and $P$ aeruginosa [35]. Lactic acid is not an appropriate acid to use against $P$. aeruginosa [35].

\section{Conclusion}

Inhibition of Salmonella strains was not solely dependent on $\mathrm{pH}$ or the concentration of undissociated organic acids. The concentration of dissociated acetic, citric, lactic and propionic acids correlated well with the $\mathrm{MIC}_{\mathrm{M}} \mathrm{s}$ of $100 \%$ of the 145 Salmonella strains. A small drop in the concentration of the dissociated organic acids may result in a large number of bacteria escaping disinfection. Therefore, an organic acid carcass wash may not provide the expected elimination of surface bacteria if the concentration of dissociated organic acid is not carefully controlled. A concentration of approximately 15, 16, 17 and $20 \mathrm{mM}$ dissociated propionic, acetic, lactic and citric acids, respectively, is suggested to be maintained when disinfecting the Salmonella serovars studied here. 


\section{Acknowledgements}

The Authors thank Seth A. Penny for technical support. This work was funded by the USDA, Agricultural Research Service. Mention of trade names, proprietary products or specific equipment is solely for the purpose of providing specific information and does not constitute a guarantee, warranty or endorsement by the U.S. Department of Agriculture and does not imply its approval to the exclusion of other products that may be suitable. Additionally, the views expressed in this article are those of the authors and do not necessarily reflect the official policy of the U.S. Department of Agriculture, or the U.S. Government.

\section{References}

1. Scallan E, Hoekstra RM, Angulo FJ, Tauxe RV, Widdowson M-A, et al. 2011. Foodborne illness acquired in the United States-major pathogens. Emerg Infect Dis 17(1): 7-15. https://doi.org/10.3201/ eid1701.P11101

2. WHO. 2016. Salmonella. Available at: http://www.who.int/topics/ salmonella/en/ (Accessed on: 14 September 2016).

3. CDC. 2016. Salmonella. Available at: https://www.cdc.gov/salmonella/ (Accessed on: 13 September 2016).

4. Hoffmann S, Macullock B, Batz M. 2015. Economic burden of major foodborne illnesses acquired in the United States, EIB-140, U.S. Department of Agriculture, Economic Research Service. Available at: http://www.cdc.gov/foodborneburden/ (Accessed on: 14 September 2016).

5. Scallan E, Griffin PM, Angulo FJ, Tauxe RV, Hoekstra RM. 2011. Foodborne illnesses acquired in the United States-unspecified agents. Emerg Infect Dis 17(1): 16-22. https://doi.org/10.3201/eid1701. P21101

6. Hsi DJ, Ebel ED, Williams MS, Golden NJ, Schlosser WD. 2015. Comparing foodborne illness risks among meat commodities in the United States. Food Control 54: 353-359. https://doi.org/10.1016/j. foodcont.2015.02.018

7. Bosilevac JM, Guerini MN, Kalchayanand N, Koohmaraie M. 2009. Prevalence and characterization of salmonellae in commercial ground beef in the United States. Appl Environ Microbiol 75(7): 1892-1900. https://doi.org/10.1128/AEM.02530-08

8. CDC. 2013. Multistate outbreak of Salmonella Montevideo and Salmonella Mbandaka infections linked to tahini sesame paste (final update). Available at: http://www.cdc.gov/salmonella/montevideotahini-05-13/signs-symptoms.html (Accessed on: 14 September 2016).

9. CDC. 2016. Multistate outbreak of Salmonella Montevideo and Salmonella Senftenberg infections linked to Wonderful Pistachios (final update). Available at: http://www.cdc.gov/salmonella/ montevideo-03-16/ (Accessed on: 14 September 2016).

10. Pakalniskiene J, Falkenhorst G, Lisby M, Madsen SB, Olsen KEP, et al. 2009. A foodborne outbreak of enterotoxigenic E. coli and Salmonella Anatum infection after a high-school dinner in Denmark, Novermber 2006. Epidemiol Infect 137(3): 396-401. https://doi.org/10.1017/ S0950268808000484

11. CDC. 2016. Eight multistate outbreaks of human Salmonella infections linked to live poultry in backyard flocks (final update). Available at: http://www.cdc.gov/salmonella/live-poultry-05-16/ (Accessed on: 13 September 2016).

12. CDC. 2011. Multistate outbreak of human Salmonella Agona infections linked to whole, fresh imported papayas (final update). Available at: http:/www.cdc.gov/salmonella/2011/papayas-8-29-2011.html (Accessed on: 14 September 2016).

13. CDC. 1985. Epidemiologic notes and reports salmonellosis associated with carne seca - New Mexico. Available at: http://www.cdc. gov/mmwr/preview/mmwrhtml/00000628.htm (Accessed on: 12 September 2016).
14. Tewari D, Sandt CH, Miller DM, Jayarao BM, M'ikanatha M. 2012. Prevalence of Salmonella Cerro in laboratory-based submissions of cattle and comparison with human infections in Pennsylvania, 20052010. Foodborne Path Dis 9(10): 928-933. https://doi.org/10.1089/ fpd.2012.1142

15. Clark M. 1996. Multistate multiple sprouts 1996. Available at: http:// outbreakdatabase.com/details/multistate-multiple-sprouts-1996/? (Accessed on: 14 September 2016).

16. CDC. 2012. Multistate outbreak of Salmonella Typhimurium infections linked to ground beef (final update). Available at: http://www.cdc. gov/salmonella/2011/ground-beef-2-1-2012.html (Accessed on: 15 September 2016).

17. Food Safety News. 2013. Salmonella Typhimurium outbreak leads to ground beef recall. Available at: http://www.foodsafetynews. com/2013/01/two-state-salmonella-typhimurium-outbreak-leads-tobeef-recall (Accessed on: 15 September 2016).

18. CDC. 2013. Multistate outbreak of Salmonella Typhimurium infections linked to ground beef (final update). Available at: http://www.cdc.gov/ salmonella/typhimurium-01-13/ (Accessed on: 15 September 2016).

19. Maguire H, Cowden J, Jacob M, Rowe B, Roberts D, et al. 1992. An outbreak of Salmonella dublin infection in England and Wales associated with a soft unpasteurized cows' milk cheese. Epidemiol Infect 109(3): 389-396. https://doi.org/10.1017/S0950268800050378

20. Vaillant V, Haeghebaert S, Desenclos JC, Bouvet P, Grimont F, et al. 1996. Outbreak of Salmonella Dublin infection in France, NovemberDecember 1995. Euro surveillance 1(2): 9-10.

21. Food Safety News. 2016. Patient count increasing in Kentucky Salmonella outbreak. Available at: http://www.foodsafetynews. com/2016/02/patient-count-increasing-in-kentucky-salmonellaoutbreak (Accessed on: 28 November 2016).

22. CDC. 2016. Multistate outbreak of Salmonella infections linked to alfalfa sprouts from one contaminated seed lot (final update). Available at: http://www.cdc.gov/salmonella/muenchen-02-16/index.html (Accessed on: 15 September 2016).

23. Beier RC, Callaway TR, Andrews K, Crippen TL, Poole TL, et al. 2017. Disinfectant and antimicrobial susceptibility profiles of Salmonella strains from feedlot water-sprinkled cattle: hides and feces. J Food Chem Nanotechnol 3(2): 50-59. https://doi.org/10.17756/jfcn.2017-037.

24. Wachsmuth IK, Sparling PH, Barrett TJ, Potter ME. 1997. Enterohemorrhagic Escherichia coli in the United States. FEMS Immunol Med Microbiol 18(4): 233-239. https://doi.org/10.1016/ S0928-8244(97)00053-9

25. Departments of Pennsylvania State University, Texas Tech University, and Washington State University. 2005. Antimicrobial spray treatments for red meat carcasses processed in very small meat establishments. Available at: http://meathaccp.wisc.edu/validation/assets/acid_spray_ intervention_booklet_from_penn_state_2005.pdf (Accessed on: 16 September 2016).

26. Raftari M, Azizi JF, Abdulamir AS, Sobhan G, Radu S, et al. 2011. Optimized antibacterial measures against Escherichia coli O157:H7 and Staphylococcus aureus. Afr J Microbiol Res 5(20): 3113-3121. https://doi. org/10.5897/AJMR10.099

27. Castillo A, Lucia LM, Roberson DB, Stevenson TH, Mercado I, et al. 2001. Lactic acid sprays reduce bacterial pathogens on cold beef carcass surfaces and in subsequently produced ground beef. J Food Prot 64(1): 58-62. https://doi.org/10.4315/0362-028X-64.1.58

28. Reynolds AE, Jr. 2005. Utilization of spray wash with organic acids (peroxyacetic acid and lactic acid) and chlorinated wash in combination, utilizing direct application methods, for pathogen reduction on pork and beef carcasses in small and very small meat processing plants. Available at: http://www.fsis.usda.gov/wps/wcm/connect/acc8bddbeb64-4ea2-82eb-565cf337691a/New_Technology_C29_Summary_ FY2003.pdf?MOD=AJPERES (Accessed on: 16 September 2016).

29. Xie Y, Savell JW, Arnold AN, Gehring KB, Gill JJ, et al. 2016. Prevalence and characterization of Salmonella enterica and Salmonella 
bacteriophages recovered from beef cattle feedlots in South Texas. $J$ Food Prot 79(8): 1332-1340. https://doi.org/10.4315/0362-028X.JFP$15-526$

30. Sofos JN, Busta FF. 1981. Antimicrobial activity of sorbate. J Food Prot 44(8): 614-622. https://doi.org/10.4315/0362-028X-44.8.614

31. Blocher JC, Busta FF, Sofos JN. 1982. Influence of potassium sorbate and $\mathrm{pH}$ on ten strains of type $\mathrm{A}$ and B Clostridium botulinum. J Food Sci 47(6): 2028-2032. https://doi.org/10.1111/j.1365-2621.1982. tb12938.x

32. Ray B, Sandine WE. 1992. Acetic, propionic, and lactic acids of starter culture bacteria as biopreservatives. In: Ray B, Daeschel M (eds) Food Biopreservatives of Microbial Origin. CRC Press, Boca Raton, FL, USA, pp 103-136.

33. Presser KA, Ross T, Ratkowsky DA. 1998. Modelling the growth limits (growth/no growth interface) of Escherichia coli as a function of temperature, $\mathrm{pH}$, lactic acid concentration, and water activity. Appl Environ Microbiol 64(5): 1773-1779.

34. Beier RC, Poole TL, Brichta-Harhay DM, Anderson RC, Bischoff $\mathrm{KM}$, et al. 2013. Disinfectant and antibiotic susceptibility profiles of Escherichia coli $\mathrm{O} 157: \mathrm{H} 7$ strains from cattle carcasses, feces, and hides and ground beef from the United States. J Food Prot 76(1): 6-17. https://doi.org/10.4315/0362-028X.JFP-12-253

35. Beier RC, Foley SL, Davidson MK, White DG, McDermott PF, et al. 2014. Characterization of antibiotic and disinfectant susceptibility profiles among Pseudomonas aeruginosa veterinary isolates recovered during 1994-2003. J Appl Microbiol 118(2): 326-342. https://doi. org/10.1111/jam.12707

36. Alakomi H-L, Skyttä E, Saarela M, Mattila-Sandholm T, Latva-Kala $\mathrm{K}$, et al. 2000. Lactic acid permeabilizes Gram-negative bacteria by disrupting the outer membrane. Appl Environ Microbiol 66(5): 20012005. https://doi.org/10.1128/AEM.66.5.2001-2005.2000

37. Beier RC, Franz E, Bono JL, Mandrell RE, Fratamico PM, et al. 2016. Disinfectant and antimicrobial susceptibility profiles of the big six non-O157 Shiga toxin-producing Escherichia coli strains from food animals and humans. J Food Prot 79(8): 1355-1370. https://doi. org/10.4315/0362-028X.JFP-15-600

38. Morrow JL, Mitloehner FM, Johnson AK, Galyean ML, Dailey JW, et al. 2005. Effect of water sprinkling on incidence of zoonotic pathogens in feedlot cattle. J Anim Sci 83(8): 1959-1966. https://doi. org $/ 10.2527 / 2005.8381959 x$

39. Clinical and Laboratory Standards Institute (CLSI). 2012. Methods for dilution antimicrobial susceptibility tests for bacteria that grow aerobically-Ninth edition. Approved standard, M7-A9. Clinical and Laboratory Standards Institute, Wayne, PA, USA.

40. Andrews JM. 2001. Determination of minimum inhibitory concentrations. J Antimicrob Chemother 48(Suppl 1): 5-16.

41. Helmenstine AM. 2014. Henderson Hasselbalch equation and example. Available at: http://chemistry.about.com/od/acidsbase1/a/ hendersonhasselbalch.htm (Accessed on: 20 September 2016).

42. Bearson BL, Lee IS, Casey TA. 2009. Escherichia coli O157:H7 glutamate- and arginine-dependent acid-resistance systems protect against oxidative stress during extreme acid challenge. Microbiology 155(3): 805-812. https://doi.org/10.1099/mic.0.022905-0

43. Rushdy AA, Mabrouk MI, Abu-Sef FA-H, Kheiralla ZH, Abdel-All $\mathrm{SM}$, et al. 2013. Contribution of different mechanisms to the resistance to fluoroquinolones in clinical isolates of Salmonella enterica. Braz J Infect Dis 17(4): 431-437. https://doi.org/10.1016/j.bjid.2012.11.012

44. Kieboom J, Abee T. 2006. Arginine-dependent acid resistance in Salmonella enterica serovar Typhimurium. J Bacteriol 188(15): 56505653. https://doi.org/10.1128/JB.00323-06

45. Gao C, Hu C, Zheng Z, Ma C, Jiang T, et al. 2012. Lactate utilization is regulated by the FadR-type regulator LldR in Pseudomonas aeruginosa. J Bacteriol 194(10): 2687-2692. https://doi.org/10.1128/JB.06579-11

46. Gao C, Hu C, Ma C, Su F, Yu H, et al. 2012. Genome sequence of the lactate-utilizing Pseudomonas aeruginosa strain XMG.J Bacteriol 194(17): 4751-4752. https://doi.org/10.1128/JB.00943-12 